\title{
Total Mercury, Methylmercury, Inorganic Arsenic and Other Elements in Meat from Minke Whale (Balaenoptera acutorostrata) from the North East Atlantic Ocean
}

\author{
Amund Maage $^{1} \cdot$ Bente M. Nilsen $^{1} \cdot$ Kaare Julshamn $^{1} \cdot$ Livar Frøyland $^{1}$. \\ Stig Valdersnes ${ }^{1}$
}

Received: 16 December 2016 / Accepted: 3 May 2017 / Published online: 2 June 2017

(c) The Author(s) 2017. This article is an open access publication

\begin{abstract}
Meat samples of 84 minke whales (Balaenoptera acutorostrata) mainly from the Barents Sea, collected between 1 May and 16 August 2011, were analyzed for total mercury, methylmercury, cadmium, lead, total arsenic, inorganic arsenic and selenium. The average total mercury concentration found was $0.15 \pm 0.09 \mathrm{mg} / \mathrm{kg}$, with a range from 0.05 to $0.49 \mathrm{mg} / \mathrm{kg}$. The molar ratio of selenium to mercury varied between 1.0 and 10.3. Cadmium content ranged from 0.002 to $0.036 \mathrm{mg} / \mathrm{kg}$, while the content of lead in whale meat ranged from $<0.01$ to $0.09 \mathrm{mg} /$ $\mathrm{kg}$. None of the whale samples exceeded established EU maximum levels for metals in fish muscle, but $4.8 \%$ and $6.8 \%$ of the samples exceeded Japanese maximum levels for total mercury and methylmercury, respectively, in whale meat. There was only minor variations in element concentrations between whales from different geographical areas, and cadmium was the only element were the concentration increased with increasing length.
\end{abstract}

Keywords Minke whale $\cdot$ Mercury $\cdot$ Barents Sea · Methylmercury $\cdot$ Inorganic arsenic $\cdot$ Selenium

Even though mercury $(\mathrm{Hg})$ is a naturally occurring element, it is regarded as a global pollutant that can impair both wildlife and human health. Of the different chemical forms of $\mathrm{Hg}$, methylmercury $(\mathrm{MeHg})$ is the most toxic and abundant in the marine food web. During the last several years, we have studied in detail the $\mathrm{Hg}$ content of two of the

Stig Valdersnes

stig.valdersnes@nifes.no

1 National Institute of Nutrition and Seafood Research, P. O. Box 2029, Nordnes, 5817 Bergen, Norway most important fish species in the Barents Sea, Atlantic cod (Gadus morhua) (Julshamn et al. 2013) and the Norwegian spring spawning herring (Clupea harengus), which spends its juvenile stage there (Frantzen et al. 2015). As the top predators are assumed to be most vulnerable to $\mathrm{Hg}$ accumulation in the Arctic (Scheuhammer et al. 2015), one can assume that whales are highly susceptible to $\mathrm{Hg}$ accumulation. The minke whale (Balaenoptera acutorostrata) in the North East Atlantic mainly forage on fish such as capelin, herring, mackerel and codfish and crustaceans such as krill (Haug et al. 2002; Pierce et al. 2004) in its main feeding seasons during spring and autumn. They eat less in the tropical breeding grounds (Morissette et al. 2010). The populations of minke whale in the North East Atlantic have been estimated by the International Whaling Commission (IWC) to contain between 64,000 and 100,000 whales over the last two decades (IWC 2016). There is still a limited hunting operation for the minke whale in the Arctic and some 1000 tons of whale meat have been put on the market annually in recent years (IMR 2016). We have studied total $\mathrm{Hg}$ (THg), MeHg, total arsenic (TAs) and inorganic arsenic (iAs) together with cadmium $(\mathrm{Cd})$, lead $(\mathrm{Pb})$ and selenium (Se) in whale meat from the 2011 hunting season to evaluate if there were differences in element concentrations with respect to sex of the animal or geographical area where the whales were caught, and whether there were any correlations between element concentrations and length of the animals.

\section{Materials and Methods}

Whale meat samples were collected from nine different whaling boats between 1 May and 16 August, 2011, in the North East Atlantic. The geographical distribution of the 
sampling localities is given in Fig. 1. A total of 84 individuals were collected from three areas: (1) area North; including 46 whales caught near Svalbard and near Bear Island $\left(74^{\circ} 16^{\prime} \mathrm{N}-77^{\circ} 21^{\prime} \mathrm{N}\right.$ and $\left.13^{\circ} 09^{\prime} \mathrm{E}-19^{\circ} 10^{\prime} \mathrm{E}\right)$, (2) area East; including 33 whales caught along the coast of northeastern Norway $\left(70^{\circ} 05^{\prime} \mathrm{N}-71^{\circ} 30^{\prime} \mathrm{N}\right.$ and $\left.19^{\circ} 09^{\prime} \mathrm{E}-31^{\circ} 19^{\prime} \mathrm{E}\right)$, and (3) area South; including five whales from coastal Norway south of $69^{\circ} \mathrm{N}$ (two whales from the area $67^{\circ} 57^{\prime} \mathrm{N}-68^{\circ} 16^{\prime} \mathrm{N}$ and $14^{\circ} 00^{\prime} \mathrm{E}-15^{\circ} 33^{\prime} \mathrm{E}$ and three whales from the area $60^{\circ} 53^{\prime} \mathrm{N}-61^{\circ} 52^{\prime} \mathrm{N}$ and $03^{\circ} 21^{\prime} \mathrm{E}-04^{\circ} 24^{\prime} \mathrm{E}$ ).

Each sample was placed into individual plastic bags and kept at $-20^{\circ} \mathrm{C}$ until the boat came to harbor. The sample was then sent overnight to our laboratory. The samples were then freeze dried, water content was determined, and further homogenized and stored in tight plastic containers until analysis. The meat samples were analyzed for $\mathrm{THg}$, $\mathrm{MeHg}, \mathrm{TAs}, \mathrm{iAs}, \mathrm{Cd}, \mathrm{Pb}$ and $\mathrm{Se}$.

For the total element analyses, two weighed samples of $0.2-0.26 \mathrm{~g}$ were digested using $2.0 \mathrm{~mL}$ of concentrated nitric acid and $0.5 \mathrm{~mL} 30 \%(\mathrm{w} / \mathrm{w})$ of hydrogen peroxide in a Milestone-MLS-1200 microwave oven (Milestone Inc., Shelton, CT, USA) as described by Julshamn et al. (2007). The measurements were performed by use of an Agilent 7500c ICP-MS (Agilent Technologies, Santa Clara, CA, USA). Results were reported as the average

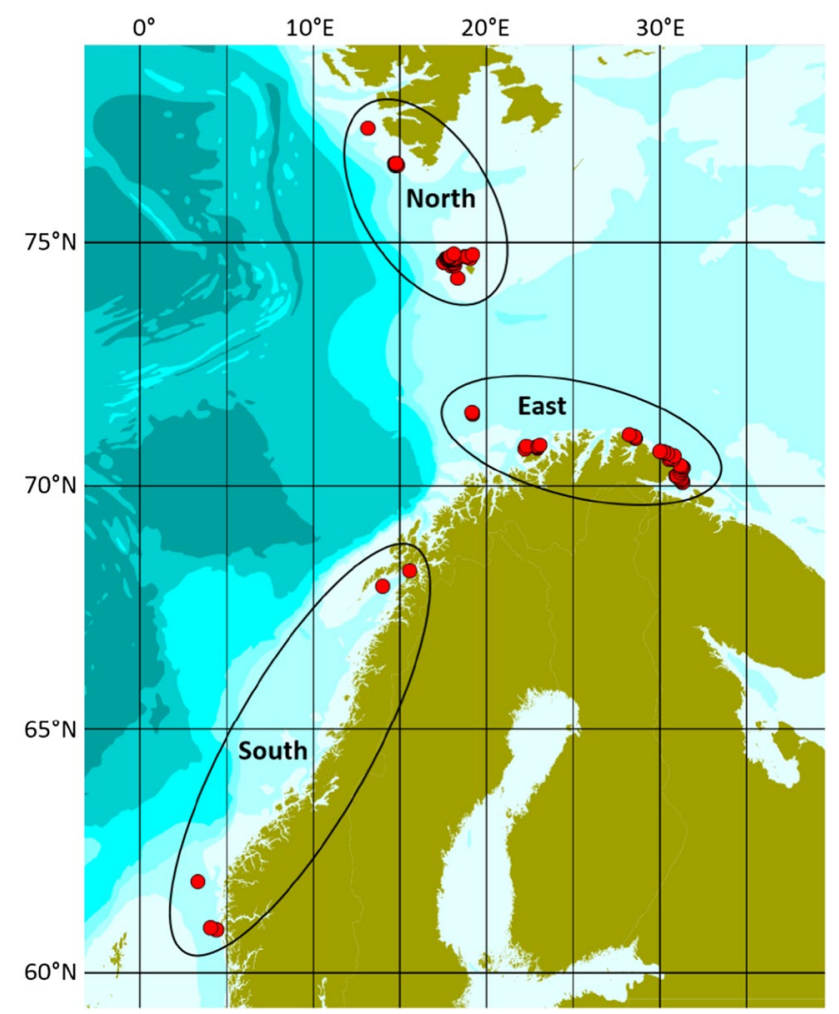

Fig. 1 Map of northern Scandinavia showing the different sampling localities and areas of two analytical parallels as required for the accreditation of the analysis. Agreement between parallels were required for the acceptance of the analytical results. A random selection of 44 out of the 84 samples were analyzed for $\mathrm{MeHg}$. The method for determining $\mathrm{MeHg}$ comprised of spiking the tissue sample with a $\mathrm{Me}^{201} \mathrm{Hg}$ enriched spike solution followed by digestion of the sample with tetramethylammonium hydroxide (TMAH), adjustment of $\mathrm{pH}$ values by $\mathrm{NaAc} / \mathrm{HNO}_{3}$, derivatisation with $\mathrm{NaBEt}_{4}$, and organic extraction of the derivatized EtMeHg into hexane. The hexane layer was subsequently analyzed by GC-ICP-MS (Agilent Technologies), and the result calculated using the isotope dilution equation (Valdersnes et al. 2012). Twenty samples of whale meat were selected and analyzed for iAs. Freeze dried material was weighed, $0.9 \mathrm{M} \mathrm{NaOH}$ in $50 \%(\mathrm{v} / \mathrm{v})$ ethanol was added and the sample was extracted in CEM MARS 5 microwave oven using GreenChem Plus Teflon bombs for $20 \mathrm{~min}$ at $90^{\circ} \mathrm{C}$ (CEM Corp., Matthews, NC, USA). The samples were cooled, centrifuged and filtered. The iAs was determined using HPLC-ICP-MS (Agilent Technologies) fitted with an ICSep ION-120 ion exchange column (Transgenomic Inc, Omaha, NE, USA). All methods are accredited by the Norwegian Accreditation Authority (Lillestrøm, NO). Quality control was done by concomitant analyses of certified reference materials (TORT-2; National Research Council, Ottawa, ON, Canada). Our results in $\mathrm{mg} / \mathrm{kg}$ for the TORT- 2 were as follows (with the certified values in parentheses): THg 0.28 $(0.27 \pm 0.06), \mathrm{MeHg} 0.160(0.152 \pm 0.013)$, TAs 22.4 (21.6 \pm 1.8$), \mathrm{Cd} 27.1(26.7 \pm 0.6), \mathrm{Pb} 0.33(0.35 \pm 0.13)$. At the time of analysis no reference materials were available for iAs, so TORT-2 was spiked with $50 \mathrm{ng}$ of both $\mathrm{As}(\mathrm{III})$ and $\mathrm{As}(\mathrm{V})$, and recoveries were found to be in the range $96 \%-102 \%$. The limits of quantification (LOQ) were $0.005,0.03,0.03,0.013,0.005,0.03$ and $0.01 \mathrm{mg} /$ $\mathrm{kg}$ dry weight for THg, $\mathrm{MeHg}$, TAs, iAs, $\mathrm{Cd}, \mathrm{Pb}$ and $\mathrm{Se}$, respectively.

Since THg, Cd, TAs and Se concentrations were skewed with long tails of high values, and displayed heteroscedasticity, the concentrations were log-transformed to remedy this. For comparison of physical parameters and element concentrations between different areas and between male and female whales, one-way analysis of variance (ANOVA) followed by Tukey's multiple comparison test were used. Linear regressions were carried out using both log-transformed and untransformed concentrations. Since both analyses gave the same conclusions, results from untransformed concentrations are reported. Dell Statistica (Dell Inc., Round Rock, TX, USA), version 13, was used for statistical analyses and graphs, and a significance level of 0.05 was selected for all analyses. 
Table 1 Length of whales $(\mathrm{cm})$ and concentration of TAs, $\mathrm{Cd}$, $\mathrm{THg}, \mathrm{Pb}, \mathrm{Se}$ and $\mathrm{MeHg}(\mathrm{mg} / \mathrm{kg}$ w.w.) in meat samples of whales from different geographical areas

\begin{tabular}{|c|c|c|c|c|}
\hline & $\begin{array}{l}\text { North }(\mathrm{N}=46) \\
\text { Mean } \pm \mathrm{SD} \\
\text { Median } \\
(\min -\max )\end{array}$ & $\begin{array}{l}\text { East }(\mathrm{N}=33) \\
\text { Mean } \pm \mathrm{SD} \\
\text { Median } \\
(\min -\max )\end{array}$ & $\begin{array}{l}\text { South }(\mathrm{N}=5) \\
\text { Mean } \pm \mathrm{SD} \\
\text { Median } \\
(\min -\max )\end{array}$ & $\begin{array}{l}\text { Overall }(\mathrm{N}=84) \\
\text { Mean } \pm \mathrm{SD} \\
\text { Median } \\
(\min -\max )\end{array}$ \\
\hline Length & $\begin{array}{l}726 \pm 91 \\
735 \\
(536-880)\end{array}$ & $\begin{array}{l}716 \pm 94 \\
717 \\
(530-910)\end{array}$ & $\begin{array}{l}683 \pm 140 \\
740 \\
(525-810)\end{array}$ & $\begin{array}{l}719 \pm 95 \\
730 \\
(525-910)\end{array}$ \\
\hline TAs & $\begin{array}{l}0.29 \pm 0.12^{\mathrm{a}} \\
0.25 \\
(0.13-0.65)\end{array}$ & $\begin{array}{l}0.19 \pm 0.08^{b} \\
0.17 \\
(0.084-0.44)\end{array}$ & $\begin{array}{l}0.28 \pm 0.12^{\mathrm{a}} \\
0.22 \\
(0.18-0.44)\end{array}$ & $\begin{array}{l}0.25 \pm 0.12 \\
0.21 \\
(0.084-0.65)\end{array}$ \\
\hline $\mathrm{Cd}$ & $\begin{array}{l}0.009 \pm 0.008 \\
0.006 \\
(0.002-0.036)\end{array}$ & $\begin{array}{l}0.007 \pm 0.007 \\
0.004 \\
(0.002-0.031)\end{array}$ & $\begin{array}{l}0.010 \pm 0.009 \\
0.007 \\
(0.002-0.025)\end{array}$ & $\begin{array}{l}0.008 \pm 0.008 \\
0.005 \\
(0.002-0.036)\end{array}$ \\
\hline THg & $\begin{array}{l}0.14 \pm 0.09 \\
0.12 \\
(0.05-0.49)\end{array}$ & $\begin{array}{l}0.16 \pm 0.09 \\
0.13 \\
(0.05-0.43)\end{array}$ & $\begin{array}{l}0.20 \pm 0.10 \\
0.15 \\
(0.11-0.35)\end{array}$ & $\begin{array}{l}0.15 \pm 0.09 \\
0.12 \\
(0.05-0.49)\end{array}$ \\
\hline $\mathrm{Pb}^{\mathrm{d}}$ & $\begin{array}{l}0.014 \pm 0.012 \\
0.009(23)^{\mathrm{c}} \\
(<0.007-0.065)\end{array}$ & $\begin{array}{l}0.012 \pm 0.014 \\
0.008(18)^{\mathrm{c}} \\
(<0.006-0.089)\end{array}$ & $\begin{array}{l}0.016 \pm 0.016 \\
0.010(3)^{\mathrm{c}} \\
(<0.008-0.045)\end{array}$ & $\begin{array}{l}0.013 \pm 0.013 \\
0.009(44)^{\mathrm{c}} \\
(<0.006-0.089)\end{array}$ \\
\hline $\mathrm{Se}$ & $\begin{array}{l}0.22 \pm 0.07^{\mathrm{a}} \\
0.19 \\
(0.15-0.49)\end{array}$ & $\begin{array}{l}0.22 \pm 0.05^{\mathrm{a}} \\
0.21 \\
(0.15-0.40)\end{array}$ & $\begin{array}{l}0.29 \pm 0.05^{\mathrm{b}} \\
0.28 \\
(0.23-0.37)\end{array}$ & $\begin{array}{l}0.22 \pm 0.06 \\
0.20 \\
(0.15-0.49)\end{array}$ \\
\hline $\mathrm{MeHg}$ & $\begin{array}{l}\mathrm{N}=30 \\
0.14 \pm 0.09 \\
0.12 \\
(0.05-0.48)\end{array}$ & $\begin{array}{l}\mathrm{N}=10 \\
0.19 \pm 0.12 \\
0.19 \\
(0.06-0.45)\end{array}$ & $\begin{array}{l}\mathrm{N}=4 \\
0.23 \pm 0.11 \\
0.21 \\
(0.14-0.36)\end{array}$ & $\begin{array}{l}\mathrm{N}=44 \\
0.16 \pm 0.10 \\
0.14 \\
(0.05-0.48)\end{array}$ \\
\hline
\end{tabular}

Letters "a" and "b" indicate significant differences $(p<0.05)$

${ }^{\mathrm{c}}$ The numbers in parentheses are the number of whale samples with $\mathrm{Pb}$ concentrations above LOQ

${ }^{\mathrm{d}}$ Upperbound concentrations, calculated on the assumption that all the values below the limit of quantification are equal to the limit of quantification, were used for calculations of $\mathrm{Pb}$

\section{Results and Discussion}

Length of the whales ranged from 525 to $910 \mathrm{~cm}$, with a mean/median of $719 / 730 \mathrm{~cm}$ (Table 1). Seven males, 75 females and two whales with unknown sex were collected. A test for difference revealed that the dataset had significantly more females than males $(p<0.0001)$. There was no significant difference in length between female and male whales or between whales from the different geographical areas (i.e. North, East and South).

The concentrations of $\mathrm{THg}, \mathrm{MeHg}, \mathrm{Cd}, \mathrm{Pb}$, TAs and $\mathrm{Se}$ in the whale meat samples are shown in Table 1. Mean, median, minimum and maximum values are shown for each geographical area and overall. A comparison of element concentrations between female and male whales revealed no significant differences, but this result must be interpreted with caution since $<10 \%$ of the whales were male. For $\mathrm{THg}, \mathrm{MeHg}, \mathrm{Cd}$ and $\mathrm{Pb}$, we found no significant differences in the concentrations between the three different geographical areas, North, East and South. For Se, however, the concentration was significantly higher in the area South compared to both areas North and East $(p<0.05)$. For TAs the levels were higher in whales from the area North compared to the area East $(p<0.0005)$. Also, the concentration of TAs in whales from the area South was higher than in the East, but this difference was not significant, which can be explained by the low number of whales in the area South. It is conceivable that differences in Se and TAs concentrations in whales from different geographical areas may reflect differences in TAs content of the prey items available in different areas. Haug et al. (2002) have found that krill is the dominant prey for minke whales in the northern Barents Sea, whereas young Norwegian spring spawning (NSS) herring is the main food for minke whales from the southern regions of the Barents Sea. This difference in prey items cannot explain, however, the difference in TAs concentration between the area North and East in this study, since krill and NSS-herring typically contain similar low levels of TAs (Edmonds and Francesconi 2003; Frantzen et al. 2015; Julshamn et al. 2012).

The concentration of THg in the meat samples of individual whales varied between 0.05 and $0.49 \mathrm{mg} / \mathrm{kg}$ wet weight (w.w.) (Table 1), and no samples had values of $\mathrm{THg}$ above the maximum level of $0.5 \mathrm{mg} / \mathrm{kg}$ w.w. established by the European Union (EU) for muscle meat of fish for human consumption (EU 2006). No maximum levels for $\mathrm{THg}$ or other elements in whale meat have been established in EU, but in Japan a maximum level of $0.4 \mathrm{mg} / \mathrm{kg}$ 
w.w. has been set for THg in whales (JMHLW 1973). Four whales $(4.8 \%)$ exceeded this Japanese limit, two from the area North and two from the area East. Since MeHg is the most toxic $\mathrm{Hg}$ compound when assessing human exposure through food (Dietz et al. 2013), we also measured $\mathrm{MeHg}$ and found that $100 \%$ of the $\mathrm{Hg}$ in the meat of minke whale was $\mathrm{MeHg}$ (Table 1). Japan has also established a maximum limit for $\mathrm{MeHg}$ of $0.3 \mathrm{mg} \mathrm{Hg} / \mathrm{kg}$ w.w., and three (6.8\%) of the 44 samples analyzed for $\mathrm{MeHg}$ exceeded this limit. All samples were below the guideline levels for $\mathrm{MeHg}$ in fish of $0.5 \mathrm{mg} / \mathrm{kg}$ set by the Codex Alimentarius Commission (CAC 2016). The mean concentration of THg in our study, $0.15 \mathrm{mg} / \mathrm{kg}$ w.w. (Table 1) was slightly lower than earlier results from the Norwegian Veterinary Institute that analyzed 64 pooled samples and 61 individual samples of minke whale from the same area in 2002. They found a mean of $0.23 \mathrm{mg} \mathrm{Hg} / \mathrm{kg}$ w.w. (Kleivane and Børsum 2003). However, our results were slightly higher than results found in minke whale meat from the Northern Pacific Ocean in samples bought from the Japanese market (Endo et al. 2003). They reported mean concentrations of $\mathrm{THg}$ of around $0.10 \mathrm{mg} \mathrm{Hg} / \mathrm{kg}$ w.w. Further, they reported mean concentrations as low as $0.03 \mathrm{mg} \mathrm{Hg} / \mathrm{kg}$ in Antarctic minke whale (Balaenoptera bonaerensis). The high percentage of $\mathrm{MeHg}$ found in our study is in line with the majority of the results found previously on whale meat from the Japanese market (Endo et al. 2005). In comparison with odontocete whales, the mysticete whales, such as minke whale, have much lower Hg levels. Typical values for meat of pilot whales (Globicephala melas) in the Northern Atlantic have been reported to be around $2 \mathrm{mg} \mathrm{Hg} / \mathrm{kg}$ w.w. (Dam and Bloch 2000). The reason for the lower levels of $\mathrm{Hg}$ in minke whale compared to pilot whale, is probably that the minke whale feed on prey with rather low $\mathrm{Hg}$ levels such as herring and krill in the north (Frantzen et al. 2015; Haug et al. 2002) and sand eel further south (Pierce et al. 2004).

We found no correlation between the $\mathrm{THg}$ concentration and the length of the whales, neither for the whole dataset nor for the individual geographical areas (results not shown). This is in contrast to results from various fish species showing increasing $\mathrm{Hg}$ concentrations with increasing age and size of the fish (Frantzen et al. 2015; Julshamn et al. 2013). Positive correlations of $\mathrm{Hg}$ with length, age and weight have also previously been documented for odontocete whales, but for these whales the correlation with $\mathrm{Hg}$ was stronger in liver than in muscle and stronger for age than for length and weight (Honda et al. 1983).

The whale meat samples in this study had low, but detectable levels of $\mathrm{Cd}$ (Table 1) with a mean/median concentration of $0.008 / 0.005 \mathrm{mg} / \mathrm{kg}$ w.w. No samples had Cd concentrations above $0.05 \mathrm{mg} / \mathrm{kg}$ w.w., which is the EU maximum level for $\mathrm{Cd}$ in fish muscle for human consumption (EU 2006). Also for $\mathrm{Pb}$, the levels were low, below or close to the quantification limit of the method for most of the samples. An upperbound mean/median level of $0.013 / 0.009 \mathrm{mg} \mathrm{Pb} / \mathrm{kg}$ w.w. was found, i.e. much lower than the EU maximum level for $\mathrm{Pb}$ in fish muscle of $0.3 \mathrm{mg} / \mathrm{kg}$ w.w. (Table 1). The TAs content in minke whale meat varied between 0.08 and $0.65 \mathrm{mg} / \mathrm{kg}$ w.w. with a mean/median concentration of $0.25 / 0.21 \mathrm{mg} / \mathrm{kg}$ w.w. This is lower than in muscle from most fish species where it is common to observe mean TAs levels higher than $1.0 \mathrm{mg} / \mathrm{kg}$ w.w. (Julshamn et al. 2012). In liver samples from pilot whale and beluga whale (Deliphinapterus leucus), As concentrations in the range of $0.17-1.27 \mathrm{mg} / \mathrm{kg}$ w.w. were reported, but As levels in the meat of these whales were not determined (Goessler et al. 1998). In our study, 20 whale meat samples were also analyzed for iAs, the most toxic form of As, and the results revealed that the levels in all samples were below the method LOQ of $0.003 \mathrm{mg} \mathrm{As} / \mathrm{kg}$ w.w. We found no correlation between the levels of TAs or $\mathrm{Pb}$ and length of the whales, neither when looking at the overall dataset nor when analyzing the individual areas separately. For $\mathrm{Cd}$ we found a positive correlation with length, which was significant for the overall dataset $(p<0.00001)$ and for the area North $(p<0.0005)$ and East $(p<0.005)$, but not South. The lack of significant correlation between Cd-concentration and length for the area South, is probably due to the low number of whales in this area. Positive correlations of $\mathrm{Cd}$ and $\mathrm{Pb}$ with age, length and weight have previously been shown for dolphins, but the levels of $\mathrm{Cd}$ and $\mathrm{Pb}$ in the dolphins were higher and the correlations were stronger for age than for weight and length, as well as stronger for $\mathrm{Cd}$ than for $\mathrm{Pb}$ for these odontocete whales (Honda et al. 1983).

The Se concentration in the whale meat varied between 0.06 and $0.49 \mathrm{mg} / \mathrm{kg}$ w.w. with a mean/median level of $0.22 / 0.20 \mathrm{mg} / \mathrm{kg}$ w.w. This level is comparable to levels found in lean fish muscle (NIFES 2017), but lower than levels found in odontocete whales (Endo et al. 2005). There was no correlation between the levels of Se and length of the whales when the overall dataset or whales from the area North and South were analyzed, but a significant negative correlation was found for whales from the area East $(p<0.05)$.

Se is suggested to have a protective role against the toxicity of $\mathrm{Hg}$ (Ralston and Raymond 2010). Linear regression analysis showed a significant positive correlation between Se and Hg $(p<0.00005)$, but there was a large variation between individual whales (Fig. 2, left). The Se:Hg molar ratio was found to be in the range of $1.0-10.3$ for individual whales with a mean/median of 4.6/4.4 (Fig. 2, right), showing an ample surplus of Se to sequester the Hg levels present. This molar excess of $\mathrm{Se}$ compared to $\mathrm{Hg}$, is typical to what has been found in many other fish species and in dolphin (Burger and Gochfeld 2012). 

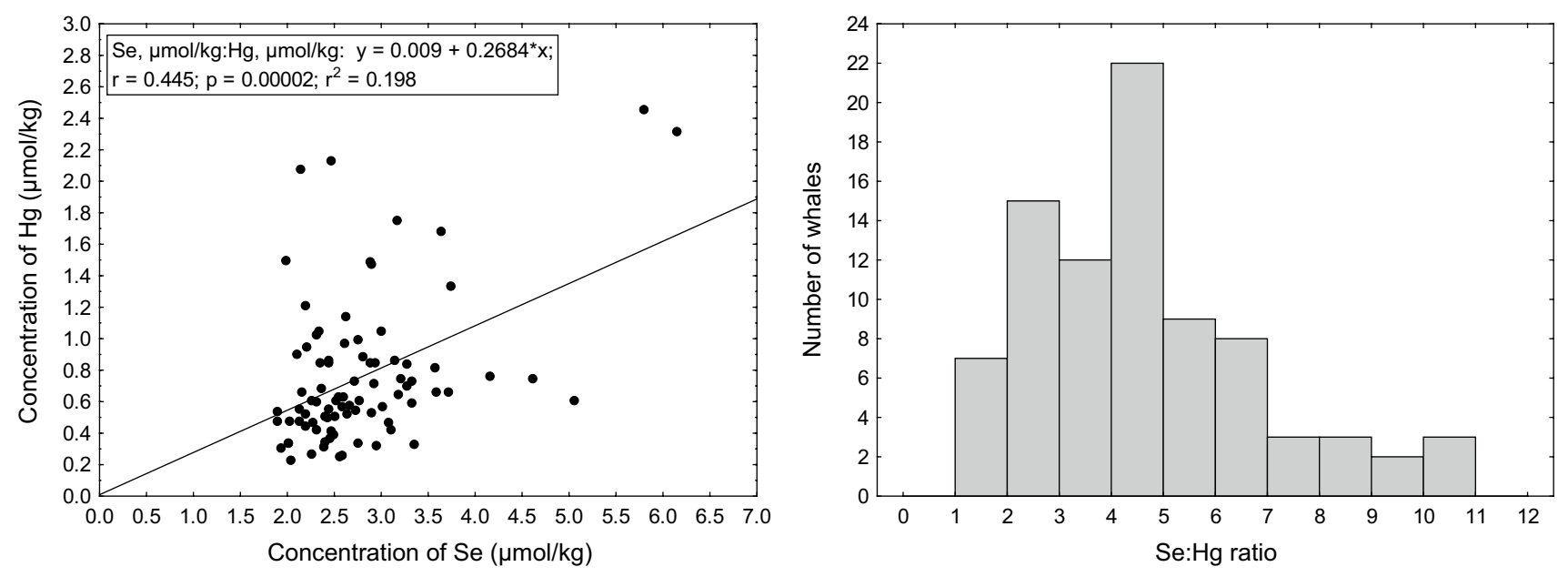

Fig. 2 Regression analysis of Se versus $\mathrm{Hg}$ (left $)$ and histogram of Se:Hg ratio (right)

In conclusion, there was little or no variation in element concentrations between whales from different geographical areas, and no difference was found between the concentrations in female and male whales. The concentration of $\mathrm{Cd}$ increased with increasing length of the whales, but no correlation was found between the levels of $\mathrm{THg}$, TAs or $\mathrm{Pb}$ and the length of the whales. Meat of minke whale contained low levels of $\mathrm{Cd}, \mathrm{Pb}$, TAs and iAs, which posed no risk from a seafood safety perspective. Moderate levels of $\mathrm{Hg}$ were found in the whale meat samples, and all the $\mathrm{Hg}$ in meat was in the form of $\mathrm{MeHg}$. However, the whale meat also contained substantial amounts of Se, which is proposed to reduce harmful effects of high $\mathrm{Hg}$ intake. For a $60 \mathrm{~kg}$ person, consumption of $100 \mathrm{~g}$ of whale meat with the highest concentration of $\mathrm{Hg}$ (i.e. $\mathrm{MeHg}$ ) found in this study $(0.49 \mathrm{mg} / \mathrm{kg}$ w.w.) would lead to an intake corresponding to $51 \%$ of the provisional tolerable weekly intake (PTWI) set by JECFA $(1.6 \mu \mathrm{g} / \mathrm{kg}$ bw) or $63 \%$ of the tolerable weekly intake (TWI) set by EFSA (1.3 $\mu \mathrm{g} / \mathrm{kg}$ bw) (EFSA 2012; JECFA 2004).

Acknowledgements We acknowledge the financial support from the Norwegian Food Safety Authority for this project, and express our gratitude to staff involved in sampling onboard whaling boats and sample processing and analytical determinations at NIFES laboratories.

Open Access This article is distributed under the terms of the Creative Commons Attribution 4.0 International License (http:// creativecommons.org/licenses/by/4.0/), which permits unrestricted use, distribution, and reproduction in any medium, provided you give appropriate credit to the original author(s) and the source, provide a link to the Creative Commons license, and indicate if changes were made.

\section{References}

Burger J, Gochfeld M (2012) Selenium and mercury molar ratios in saltwater fish from New Jersey. Individual and species variability complicate use in human health fish consumption advisories. Environ Res 114:12-23. doi:10.1016/j.envres.2012.02.004

CAC (2016) FAO/WHO Codex alimentarius commission codex stan 193-1995 general standard for contaminants and toxins in food and feed adopted in 1995, Revised in 1997, 2006, 2008, 2009, Amended in 2010, 2012, 2013, 2014, 2015, 2016

Dam M, Bloch D (2000) Screening of mercury and persistent organochlorine pollutants in long-finned pilot whale (Globicephala melas) in the Faroe Islands. Mar Pollut Bull 40:1090-1099. doi:10.1016/s0025-326x(00)00060-6

Dietz R et al (2013) What are the toxicological effects of mercury in Arctic biota? Sci Total Environ 443:775-790. doi:10.1016/j. scitotenv.2012.11.046

Edmonds JS, Francesconi KA (2003) Organoarsenic compounds in the marine environment. In: Organometallic compounds in the environment. Wiley, Hoboken, pp 195-222. doi:10.1002/0470867868.ch5

EFSA (2012) Scientific opinion on the risk for public health related to the presence of mercury and methylmercury in food. EFSA $\mathbf{J}$ 10:2985

Endo T, Hotta Y, Haraguchi K, Sakata M (2003) Mercury contamination in the red meat of whales and dolphins marketed for human consumption in Japan. Environ Sci Technol 37:2681-2685. doi:10.1021/es034055n

Endo T, Haraguchi K, Hotta Y, Hisamichi Y, Lavery S, Dalebout ML, Baker CS (2005) Total mercury, methyl mercury, and selenium levels in the red meat of small cetaceans sold for human consumption in Japan. Environ Sci Technol 39:5703-5708. doi:10.1021/es050215e

EU (2006) Commission regulation (EC) No 1881/2006 of 19 December 2006 setting maximum levels for certain contaminants in foodstuffs. Off J Eur 364:5-24

Frantzen S, Maage A, Duinker A, Julshamn K, Iversen SA (2015) A baseline study of metals in herring (Clupea harengus) from the Norwegian Sea, with focus on mercury, cadmium, arsenic and lead. Chemosphere 127:164-170. doi:10.1016/j. chemosphere.2015.01.037

Goessler W, Rudorfer A, Mackey EA, Becker PR, Irgolic KJ (1998) Determination of arsenic compounds in marine mammals 
with high-performance liquid chromatography and an inductively coupled plasma mass spectrometer as element-specific detector. Appl Organomet Chem 12:491-501. doi:10.1002/ (sici) 1099-0739(199807)12:7<491::aid-aoc740>3.3.co;2-y

Haug T, Lindstrom U, Nilssen KT (2002) Variations in minke whale (Balaenoptera acutorostrata) diet and body condition in response to ecosystem changes in the Barents Sea. Sarsia 87:409-422. doi $: 10.1080 / 0036482021000155715$

Honda K, Tatsukawa R, Itano K, Miyazaki N, Fujiyama T (1983) Heavy-metal concentrations in muscle, liver and kidney tissue of striped dolphin, Stenella coeruleoalba, and their variations with body length, weight, age and sex. Agric Biol Chem 47:1219-1228

IMR (2016) Minke Whale-status, advice and catch (in Norwegian). http://www.imr.no/temasider/sjopattedyr/hval/ vagehval_nise_springere/status_rad_og_fangst_2010/ status_rad_og_fangst_2010/nb-no

IWC (2016) Whale population estimates-the International Whaling Commission's most recent information on estimated abundance. https://iwc.int/estimate

JECFA (2004) Evaluation of certain food additives and contaminants Sixty-first report of the joint FAO/WHO expert committee on food additives. WHO Technical Report Series 922:132-140

JMHLW (1973) Provisional standard of mercury in fish and shellfish. Director-General of Environmental Health Bureau, Japanese Ministry of Health, Labour and Welfare, Notice Kannyu No. 99

Julshamn K, Maage A, Norli HS, Grobecker KH, Jorhem L, Fecher P (2007) Determination of arsenic, cadmium, mercury, and lead by inductively coupled plasma/mass spectrometry in foods after pressure digestion: NMKL interlaboratory study. J AOAC Int 90:844-856

Julshamn K, Nilsen BM, Frantzen S, Valdersnes S, Maage A, Nedreaas K, Sloth JJ (2012) Total and inorganic arsenic in fish samples from Norwegian waters. Food Addit Contam Part B 5:229-235 doi:10.1080/19393210.2012.698312

Julshamn K, Duinker A, Nilsen BM, Frantzen S, Maage A, Valdersnes S, Nedreaas K (2013) A baseline study of levels of mercury, arsenic, cadmium and lead in Northeast Arctic cod (Gadus morhua) from different parts of the Barents Sea. Mar Pollut Bull 67:187-195. doi:10.1016/j.marpolbul.2012.11.038

Kleivane L, Børsum J (2003) Undersøkelse av kvikksølvnivåer i muskel fra vågehval. 2002 report (in Norwegian). http:// www.vetinst.no/rapporter-og-publikasjoner/rapporter/2003/ underskelse-av-kvikkslvniver-i-muskel-fra-vgehval-2002

Morissette L, Kaschner K, Gerber LR (2010) 'Whales eat fish?' Demystifying the myth in the Caribbean marine ecosystem. Fish Fish 11:388-404. doi:10.1111/j.1467-2979.2010.00366.x

NIFES (2017) Seafood data. https://sjomatdata.nifes.no

Pierce GJ, Santos MB, Reid RJ, Patterson IAP, Ross HM (2004) Diet of minke whales Balaenoptera acutorostrata in Scottish (UK) waters with notes on strandings of this species in Scotland 1992-2002. J Mar Biol Assoc UK 84:1241-1244. doi:10.1017/ S0025315404010732h

Ralston NVC, Raymond LJ (2010) Dietary selenium's protective effects against methylmercury toxicity. Toxicology 278:112-123. doi:10.1016/j.tox.2010.06.004

Scheuhammer A et al (2015) Recent progress on our understanding of the biological effects of mercury in fish and wildlife in the Canadian Arctic. Sci Total Environ 509:91-103. doi:10.1016/j. scitotenv.2014.05.142

Valdersnes S, Maage A, Fliegel D, Julshamn K (2012) A method for the routine determination of methylmercury in marine tissue by GC isotope dilution-ICP-MS. J AOAC Int 95:1189-1194. doi:10.5740/jaoacint.11-133 